\title{
Factors that affect the Availability and Adequacy of Food and Its Influence against Food Resilience in the Border of Sambas District
}

\author{
${ }^{1}$ Abdul Hamid A Yusra, ${ }^{2}$ Irham, ${ }^{2}$ Slamet Hartono and ${ }^{2}$ Lestari Rahayu Waluyati \\ ${ }^{1}$ Faculty of Agriculture, Tanjungpura University, Jl. Prof Hadari Nawawi, Pontianak, Indonesia \\ ${ }^{2}$ Faculty of Agriculture, Gadjah mada University, Jl. Flora, Bulaksumur, Yogyakarta, Indonesia
}

Received date: 19 July 2018, Accepted date: 15 August 2018, Online date: 1 September 2018

Address For Correspondence:

Abdul Hamid A Yusra, Faculty of Agriculture, Tanjungpura University, J1. Prof Hadari Nawawi, Pontianak, Indonesia. E-mail: hamidyusra@gmail.com

Copyright $(92018$ by authors and American-Eurasian Network for Scientific Information. This work is licensed under the Creative Commons Attribution International License (CC BY). http://creativecommons.org/licenses/by/4.0/

\section{(c) (i) Open Access}

\begin{abstract}
This study aims to determine the factors that affect the availability and adequacy of food and its effects on the food security of farm households in the border area. The research location was chosen purposively (purposive sampling) from district level to village level in two subdistrict coastal and inland areas. This study used a survey method with 265 respondents taken randomly from a population of 1121 farmer group members. The data were analyzed using SEM-PLS method 3. The results showed that $t$-value value $\geq 1.96$ and $p-$ valus value $\leq 0.05$ which means that all the variables have significant effect on food availability and on food sufficiency. Rsquare value 0.645 means that all variables (availability of food, food sufficiency, rice stock, IDDL, distance to market and distance to puskesmas) can explain $64,5 \%$ influence food security, the rest is influenced by other factors not included in this model. The availability of food is reflected by the production of rice from farmers' household farms with the outer loading coefficient of path (0.939) the largest among other variables, corn reserves $(0.914)$, cassava reserves $(0.846)$, sweet potato stock $(0.823)$ and sourced from buy rice $(-0.760)$. Food sufficiency is reflected by the largest price of meat $(-0,847)$ among others, followed by the frequency of meetings of farming mothers in village organization activities $(0.822)$, fish prices $(0.624)$, number of family members $(0.469)$ and farm income $(0.464)$. Furthermore, the food resilience was reflected by the land carrying capacity index (0.922), the largest among others, rice reserves $(0.756)$, farmers' market distance (0.422), food sufficiency (0.417), food availability (0.398) and distance farm household to health service center ($0.316)$. Viewed from the category of food security most (78\%) of farm households in the border area in food-prone conditions to less food.

KEY WORDS

Availability of food, food sufficiency, food security, border area
\end{abstract}

\section{INTRODUCTION}

The decrease of crops, especially in the wield of fields reduced from 10,482 ha (in 2010) to 5,562 ha (in 2014) or lessen by $46.9 \%$ accompanied by increased of palm oil plantation within four years to 20,214 ha (increased $37.16 \%$ ) is a serious problem that local governments must facerelated to food self-sufficiency efforts, especially rice and food programs also balanced nutrition. [1]. The changes of agricultural land use into oil palm plantations in the border area in the coastal area increased to 1332 ha for four years and in the rural area increased to 5225 ha for two years. $[2,11]$. There is a negative correlation between the area of plantation with the area of agriculture.

The narrower agricultural area that can be used for food crops has resulted in declining rice and other food production that can be provided to farm households $[17,19]$ which domiciled in the border area of Sambas district. This will encourage in rising prices of rice and other foodstuffs thus affecting the amount of food that can be bought and consumed by farm households. The availability of food that can be consumed determines the 
adequacy and diversity of food and nutrients consumed by farmer households so as to meet balanced nutritional value, both quantity and quality as per requirement to fulfill the pattern of food expectation of PPH [13, 21]. Facts in the field show that farmers' households in the border area dependence on rice from outside the village are quite high and this is evident from the rising prices of rice and other food especially during the rainy seasonwhich deteriorated road conditions and transportation. This is the problem of encouraging researchers to conduct an assessment of the availability and adequacy and influence on food resilience in the border area.

From Monek (2007) research it's concluded that the diversity of people's food is influenced by (a) the level of knowledge of Indonesian people, especially the lower middle class is relatively low. (b) The eating culture is a difficult habit to change (c) Rice is positioned as a pre-eminent food and (d) there has been no innovation in the field of food diversity. [6,3]

Hardinsyah.dan Victor (2010) explained that the nutritional adequacy rate (AKG) is useful as a benchmark in the assessment and planning of food consumption including energy adequacy (AKE), protein adequacy (AKP), fat adequacy (AKL), and fiber adequacy (AKS). [7,21]. Regulation of the Minister of Health of the Republic of Indonesia Number 75 Year 2013 has stipulated that the recommended Nutritional Nutrition Rate for Indonesia for 2015 is 2150 Kilo calories per capita per day and 57 grams of protein for each person in a day at consumption level.

Retnaningsih et al. (2011) concluded that the nutritional adequacy of protein and energy (calories) is largely determined by the type of work. education level and income level of father. Meanwhile, diversity of education level type of work and level of education of mothers result there is no significant difference. $[9,16,22]$

National Economic Survey / SUSENAS BPS (2013) recommends that the minimum daily caloric intake should be diverse, covering 13 food groups used in the society consumption, namely; (1) grains, (2) tubers, (3) fish, (4) meat, (5) eggs and milk, (6) vegetables, (7) nuts, (8) fruits, (9) oils and fats, (10) beverage ingredients, (11) spices, (12) other consumption, and (13) finished food and drinks. Consumption of these foods will affect the number of calories produced per day. .

Farmers' households in border areas are heavily dependent on rice from outside the village, especially goods from Malaysia due to the distance to the border of Malaysia is closer. Due to the reduced agricultural area which tends to be followed by the decreasing of food availability in the border area, thus research on the factors that affecting food availability and sufficiency becomes very important to do.

Indonesia law No. 18 of 2012 on food stipulates that food availability is a condition of the availability of food from domestic production and national food reserves and imports if the two main sources can not meet the needs [21]. According to Hanani (2012) basically food security consists of three main subsystems, namely food availability (Food Availability) covering AKE 2200Kcal / capita / day, AKP 57 grams / capita / day, food reserve $\geq 20 \%$ of requirement, access (Food Access ) covers a maximum of $10-25 \%$ price stability, access to market information systems, food expenditure $<80 \%$ of revenues, public transport and food utilization covers $\mathrm{AKE} \geq 2000 \mathrm{kkal} /$ capita / day, AKP $\geq 52$ gr / capita / day, PPH 100 while nutritional status (Nutritional status) is an outcome of food security. [6].

This study aims to analyze and determine the factors that affect the availability and adequacy of household food of farmers and its influence against food resilience in the border area.

\section{Research Method:}

This research utilize survey and research location method starting from district, sub district and village chosen purposively (Purposive sampling) that is line I region bordered directly with Malaysia state. The population in this study were all members of farmer group 1.121 orang with sample 265 respondents determined by Slovin method. The sample of respondents was taken by simple random sampling [19] spread in 11 hamlets from seven villages namely Temajuk village and the Central River village of the Paloh kecamtan coastal area and five villages from the inland areas of SajinganBesar sub-district (Sebunga, Kaliau, Senatab, Sentaban and Baning Rivers).

\section{Data Analysis:}

1. Availability of staple food equivalent of rice:

The availability of staple food equivalent of rice (rice, corn, cassava and sweet potato) is equal to the rice calorie referred to as the production of basic food Netto given the code of $\mathrm{P}_{\text {food }}[6,3]$. $\mathrm{P}_{\text {food }}=$ Rnet + Jnet + UKnet + UJnet

\section{Information:}

Pfood $=$ Production of food net (rice, corn, wood uni, sweet potato)

Rnet $=$ clean rice ready for consumption

Jnet $=$ corn ready to be consumed

UKnet = clean cassava ready for consumption

UJnet $=$ clean sweet potatoes ready for consumption 
2. Food sufficiency can be calculated through the AKE score:

Then the contribution of AKE multiplied by the weight of each group of food [13].

Energy Sufficiency Rate (AKE): Ei = [(Bi x KEi / $100 \times(B D D i / 100)] / J A K$

Protein Sufficiency Rate (AKP): Pi $=\{(\mathrm{Bi} \times \mathrm{x}$ KPI $/ 100 \times(\mathrm{BDDi} / 100)\} / \mathrm{JAK}$

\section{Information:}

$\mathrm{Bi}=$ Materials consumed

$\mathrm{KEI}=$ energy contained in food ingredients consumed

$\mathrm{BDD}=$ edible parts per $100 \mathrm{~g}$ of food

$\mathrm{JAK}=$ number of family members.

Verify the AKE score of each food group with maximum score with the condition use maximum score if score AKE > maximum score. Calculate the total score of the Food Pattern of Hope (PPH) (with an ideal score of 100)

Actual calories:

Percentage Energy sufficiency rate AKE = ------------------ x 100\%

Recommended calories

Score AKE = AKE x Weight value

PPH score is obtained by comparing AKE Score with Maximum Score. When the AKE score is greater than the Maximum Score then the Maximum Score is used and also when the AKE Score is smaller than the Maximum Score then the AKE Score is used. The sum of the PPH scores for all these nutrients results in the PPH score of farmers' households in the border area which is a maximum value of 100. The percentage of the actual protein adequacy ratio (PPA) divided by the total of the PPA is normatively obtains the percentage of the PPA. Then the actual percentage of AKP compared to the normative scene. If the percentage of TKP> TKP normative then used normative crime scene number. If the percentage of TKP is <TKP normative, then this number is used to get TKPH.

3. Food Resilience Include Three Aspect:

Aspects of food availability include a) monthly savings (Rp). b) Food stock (rice) per month (\%) c) Key food availability index (Ikpp) and d) Land carrying capacity index (IDDL) [ 7 ]. Access to food aspects include: a) Onfarm revenue Rp / month; b) Offfarm revenue Rp / month; Nonffarm income Rp / month d) home range tangag to market. Aspects of food utilization include: a) Energy sufficiency rate (AKE); b) Scores of Food Patterns of Hope / PPH and c) distance of farm household to public health center (puskesmas)

All food resilience indicators are arranged in a matrix and given a score of $1-5$. Then by summing the scores and dividing into five categories of food security it will be known that a farmer's household is included in the food-susceptible or highly food-resistant category as follows:

1. Very Food Resistance if it is on the number of scores between mean +2 std

2. Hold food if it is on the number of scores between mean +1 std

3. Lack of food resistance if it is on the number of mean scores

4. Vulnerable to food if it is on the number of scores between mean - 1 std

5. Food insecurity if it is on the number of mean score - 2 std

Furthermore, to know the factors that influence food availability, food sufficiency and factors affecting the food resilience of farmers household in border area used multivariate analysis with equality modeling equation modeling (SEM) with SEM Smart PLS program with the following equation [5] :

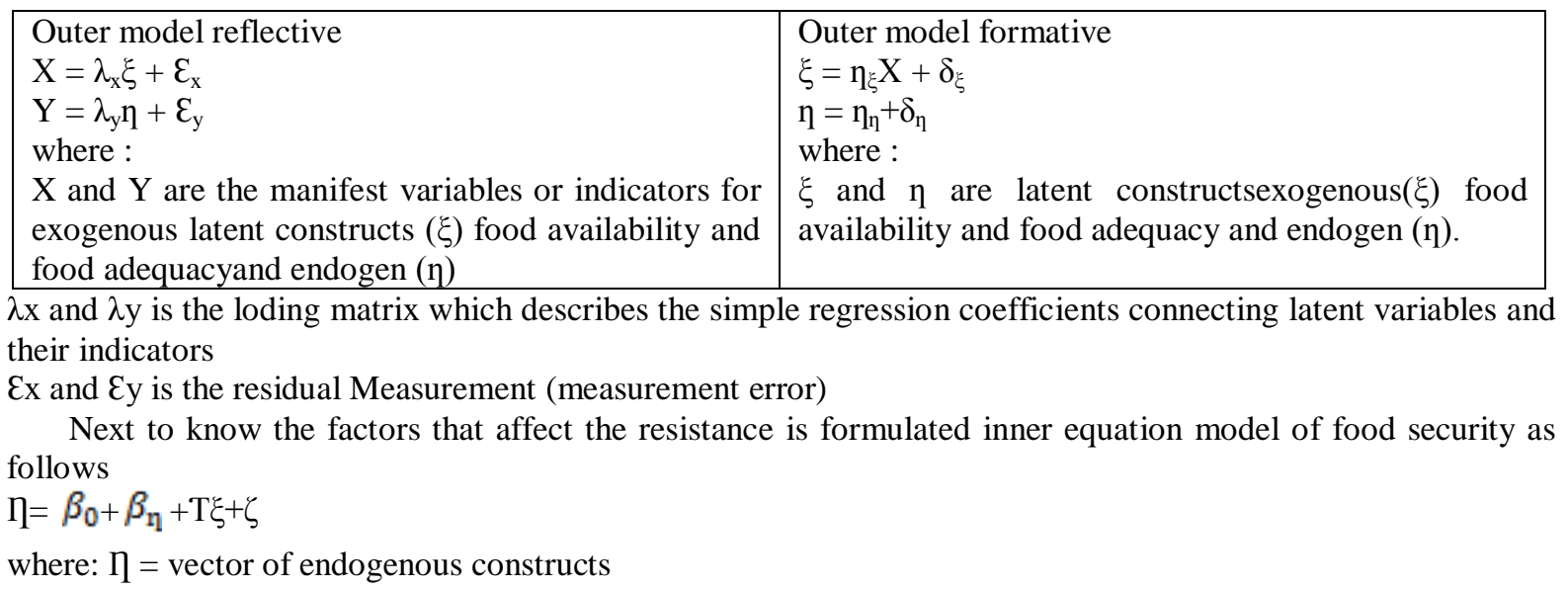


$\xi=$ vector exogenous construct

$\zeta=$ vector of residual variables (unexplained variance)

Evaluation of Model Accuracy Measurement:

To explain the relationship between exogenous variables (food availability, food sufficiency) and endogen (food resilience), between indicator and its construct in this research used SEM SmartPLS program. Haryono explains that there are some test equipment for model accuracy test and reflective model measurement; there are Coefficient Value Loading Factor must be> 0.7, Composite Reliability value, measuring internal consistency must be> 0.6, Average Variance Extracted (AVE), Discriminant Validity value of the square root of the AVE must be> the correlation value between latent variables, Cross Loading expected for each block indicator has a higher loading value for latent variable measured compared to the indicator for other latent variables. [5].

The measurement of the formative model seen from the significance of the weight value and the two multicollinearity between variables can be seen from the VIF value $>10$ this indicating there are symptoms of multicollinearity. First step is to evaluate the structural model R square from endogen latent variable, from this it can be indicatedthat the model is good, moderate or weak. Second, estimation of coefficients path must be significantly obtained with the bootstrapping procedure thatthe result should produce $\mathrm{T}$ (T-value). Third, to sees $\mathrm{f}^{2}$ for the effect size that can be interpreted whether the predictor variable has a weak, medium or large influence on the structural level and fourth view of the predefined relevance of $\mathrm{Q}^{2}$ and $\mathrm{q}^{2}$. [5, 10]

According to Ghozali and Hengky (2014) the factor loading values are tolerable to $\geq 0.60$ for exploratory research, the AVE is $>0.50$ for confirmation or exploratory, cross loading should be $>0.70$ for each variable, the square root $>$ from correlation between construct latent, cronbach's Alpha between $>0.60$ and for exploratory research and composite reliability values is between 0.6-0.70. Haryono (2017: 372) mentions, in empirical research loading factor value is $\geq 0.5$ still can be accepted even some scientists tolerate up to value 0.4.

\section{Research Result And Discussion:}

The first testevaluated the model against the individual item reliability that can be seen from the standardized loading factor value (Table 7.1).

Table 7.1 has provided information that the process from SEM Smart PLS 0.3 produced two relationship models; the reflective model that is the relationship between the indicator / manifest and the construct / latent variable. The second relationship is a formative model that is the relationship between exogenous latent variables and endogenous variables.

The first exogenous variable is the availability of food (KS) with five indicators formation; rice from farm produce, monthly rice purchase, cassava alternative supply, sweet potato and corn alternative supply that not sold by farmers. The second exogenous variable is food sufficiency (KCP) which is formed by the price of fish and meat, montly the farmer's income, frequency of the mother of household participation in organization activity in village and number of family member. The third latent variable is food resilience (KTP) as endogenous latent variable with its alternative indicatorsare rice, land carrying capacity, and the distance of the farmer household to market public health service.

According to the first test result that required in the loading factor $\geq 0.4$ only the indicator of household distance to the health service center is $<0.4$ in general, all indicators can be conclude are valid (Table 7.1).

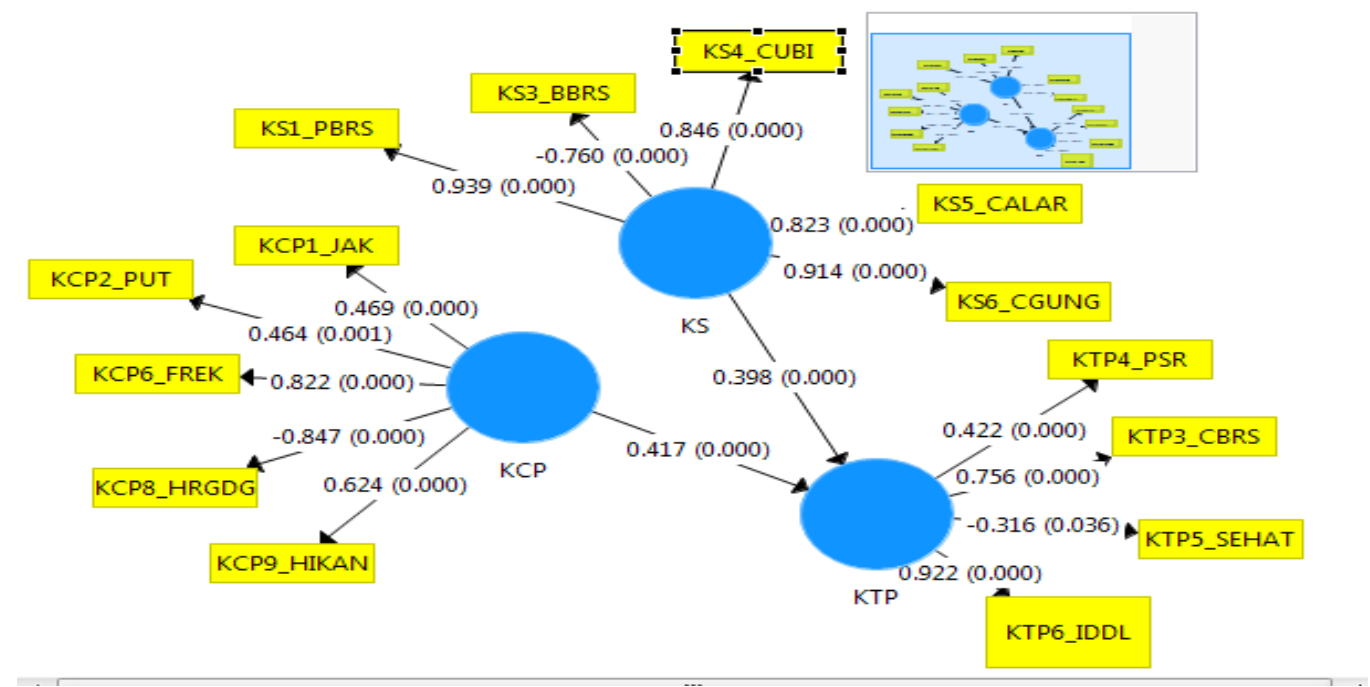

Table 7.1 Coefficient Output in Struktural Line of Food Resilience: 
The second test focus at the Composite reliability that requires a value of $>0.6$. The results showed that the correlation coefficient value of KS 0.853 which shown $85.3 \%$ consistency of each indicator can measure KS construct. Meanwhile the indicators consistent value of KCP and KTP for each supporting indicatoronly $45.7 \%$ and $58.0 \%$. (Table 7.2)

The third model test requires an Average Varian extracted (AVE) $\geq 0.5$. The value of AVE is used to measure the amount of variance that can be capture by the construct, compared to the other variance that caused by the misuse of measurement. The analysis result shows the construct coefficient KS value is 0.736 higher than 0.5 which means $73.6 \%$ variant from indicator constructor that can be described by KS construct variable. While the coefficient value of KCP and KTP is 0.479 and 0.425 , which means that the ability to capture of variant caused by the indicator is only $47.9 \%$ and $42.5 \%$ (Table 7.3 ).

The fourth test validity is by looking at the discriminant validity from the square root of AVE and Cross loading. The square root of AVE should be greater than the correlation between latent variables of food resilience. Table 7.4 shows that the square root of AVE value is higher than between the correlation value construct, therefore the model is valid (appendix 7.4).

The fifth validity test by evaluating discriminant validity of dapa cross loading from reselience food construct. The results is the sufficiency block is greater than the availability block and this availability block more higherthan the reselience block this can be said to be valid (appendix 7.5). There are five validity tests model that have been carried out on the reflective model and can be stated all indicator are valid measurements to explain the latent construct.

The next step is to evaluate the structural model. Firstly by looking at the R2square which indicates a wellformed model is good (0.67-0.75), moderate $(0.33-0.50)$ or weak (0.19-0.25). Secondly, Test of estimationcoefficientpath by looking at Tvalue thatshowing its relation between the paths must be significant. Thirdly, to see coefficient value effect of size $\mathrm{f}^{2}$ that can interpret the influence of predictor; small (0.02) medium (0.15) or magnitude (0.35). The fourth test by looking at the value of $\mathrm{Q}^{2}$ and $\mathrm{q}^{2}$ predictive relevance. If Q2 $\geq 0$ indicates the model has predictive relevance and if $\mathrm{Q} 2 \leq 0$ indicates the model lacks predictive relevance. If $\mathrm{q} 2$ is 0.02 it can be considering weak, and moderate (0.15) and strong (0.35) [5]

The result of analysis shows $\mathrm{R}$ square adjusted equal to 0.40 and its included into moderate $(0,30-0,50)$, the meaning is exogenous force variable (KCP and KS) explain endogen variable (KTP) only 40,9\% and remaining $59,1 \%$ is influenced by another factor that doesn't inlcuded in. Standard Model meansurementused. (Table 7.6)

The second test result seen from the path coefficient KCP-> KTP $0.417 * * *$ with Tvalue 5.733> 1.96 and KS-> KTP $0.398 * *$ with Tvalue 4.647> 1.96 shows significant thus it can be said that the structural model is valid (Table 7.7).

The third measurement model by measuring the effect size $\mathrm{f}^{2}$ by looking at the strong and weakness from relation of predictor to KTP through each KCP and KS variables with the value is 0.279 and 0.254 , which means in the middle position (0.15), small (0.02) and large (0.35) (Appendix Table 7.8 ).

The last test of the fourth model is prediction of the relevance of exogenous variables to the endogenous variables through the value of R squre KCP 0.595 and KS 0.392. with the formula:

$\mathrm{Q}^{2}=1-\left(1-\mathrm{R}_{1}^{2}\right)\left(1-\mathrm{R}_{2}^{2}\right)$

$\mathrm{Q}^{2}=1-\left(1-0.595^{2}\right)\left(1-0.392^{2}\right)$

$\mathrm{Q}^{2}=1-(0.546)$

$\mathrm{Q}^{2}=0.454$

$\mathrm{Q}^{2}>0$ (indicates the model is relevant, valid)

Therefore the value of $\mathrm{Q}^{2}>0$ then the structural model is valid. Based on all the tests that have been done then it is concluded that all indicators and latent variables that form the overall structural model has a validity (Table 1).

Table 1: Factors Affecting Availability, Food Sufficiency and Food Resilience.

\begin{tabular}{|c|c|c|c|c|c|c|c|c|}
\hline \multicolumn{3}{|l|}{ Food Availability } & \multicolumn{3}{|l|}{ Food Sufficiency } & \multicolumn{3}{|l|}{ Food Resilience } \\
\hline & Loding & & & loding & & & loding & \\
\hline Hypothesis & Factor & T-value & Hypothesis & Factor & T-value & Hypothesis & Factor & $\mathrm{T}$-value \\
\hline $\begin{array}{l}\text { KS1_PBRS <- } \\
\text { KS }\end{array}$ & 0.939 & 68.827 & $\begin{array}{l}\text { KCP1_JAK <- } \\
\text { KCP }\end{array}$ & 0.469 & 6.299 & KCP $->$ KTP & 0.417 & 5.66 \\
\hline $\begin{array}{l}\text { KS3_BBRS <- } \\
\text { KS }\end{array}$ & -0.76 & 24.19 & $\begin{array}{l}\text { KCP2_PUT <- } \\
\text { KCP }\end{array}$ & 0.464 & 3.202 & KS -> KTP & 0.398 & 4.544 \\
\hline $\begin{array}{l}\text { KS4_CUBI <- } \\
\text { KS }\end{array}$ & 0.846 & 21.845 & $\begin{array}{l}\text { KCP6_FREK <- } \\
\text { KCP }\end{array}$ & 0.822 & 23.989 & $\begin{array}{l}\text { KTP3_CBRS <- } \\
\text { KTP }\end{array}$ & 0.756 & 8.908 \\
\hline $\begin{array}{l}\text { KS5_CALAR <- } \\
\text { KS }\end{array}$ & 0.823 & 19.691 & $\begin{array}{l}\text { KCP8_HRGDG } \\
<- \text { KCP }\end{array}$ & -0.847 & 15.122 & $\begin{array}{l}\text { KTP4_PSR }<- \\
\text { KTP }\end{array}$ & 0.422 & 3.524 \\
\hline $\begin{array}{l}\text { KS6_CGUNG } \\
<-\mathrm{KS}\end{array}$ & 0.914 & 31.353 & $\begin{array}{l}\text { KCP9_HIKAN } \\
\text { <- KCP }\end{array}$ & 0.624 & 11.073 & $\begin{array}{l}\text { KTP5_SEHAT <- } \\
\text { KTP }\end{array}$ & -0.316 & 2.041 \\
\hline $\begin{array}{l}\text { KS1_PBRS <- } \\
\text { KS }\end{array}$ & 0.939 & 68.827 & $\begin{array}{l}\text { KCP1_JAK <- } \\
\text { KCP }\end{array}$ & 0.469 & 6.299 & $\begin{array}{l}\text { KTP6_IDDL <- } \\
\text { KTP }\end{array}$ & 0.922 & 60.511 \\
\hline
\end{tabular}


Factors Affecting the Food Availability in Farmers / Fishermen Household:

Haryono explains that the acceptable loading factor values as required are $\geq 0.7$ but some experts agree to lowering and tolerate up to value $\geq 4$. The value of this coefficient can be seen in the outer loading or on the path coefficient diagram. Based on the analysis result with SEM Smars PLS program approach in Picture it is known that all loading factor is $>4$ and significant means that the model have been used was fit and qualified to explain that food availability is strongly correlated with the indicator.

Figure 7.1. demonstrates that there are seven indicators that reflect farmers' household food availability; total amount produce of rice converted within a month, the number of family members (JAK). the amount of rice purchased for each month, rice alternative supply at the end of each month and amount of corn production that does not for sale. The results of the analysis within the picture, loading factor model and Table 7.1 can be explained that all indicators that reflect the availability of food is strongly correlated. Sequentially the variabel manifest or indicator that qualifies the convergence of validity to explain the household food availability of farmers can be known from the outer loading coefficient.

The value of the correlation coefficient can be sorted from the highest to the low which illustrates the closeness of the relationship with the construct. The highest value means having the closest relation with the availability of food. Saving corn commodities (not for sale) have the highest coefficient of 0.953 . As already explained that not all crops such as corn, cassava and sweet potato are sold by farmers that are prepared as food saving in urgent circumstances. The saving of corn is usually still intact in the form of leafy stalkand storage in the kitchen. Currently only a small percentage of farmers that using the traditional way of storing corn because they are still maintains cooking using the wood stove fire furnace. Storage of kernel corn in cans is now done by many farmers for reasons more easily packed and more safer from pests and fungi because it is stored in a dry state. To serve as rice substitute, corn usually is mashed up first until the size of rice before its consume.

Rice from self-production results correlated positively and significantly to food KS $(0,950)$ indicating rice product from farming system including saving sweet potatoes $(0,947)$ and rice saving supply at end of month $(0,856)$ greatly determines the availability food of farmers household. In other words, each indicator is a large contribution by building construction with $95 \%$ of self-production rice, $94.7 \%$ of sweet potatoes and $85.6 \%$ comes from month-end saving food.

Then the number of family members connection with the availability of household food is more directed to the aid of labor in conducting farming activities. The more members of the family who work, the better the preparation for farming is done, it will be faster and easier. The work load becomes lighter and everything can be handled according to plan.

Based on the coefficient value of correlation outer model can be explained as follows; First. the availability of food is reflected by self-produced rice by the farmers independently. The close relationship of production with food availability reaches 93.9 percent, it means that if rice production can be producedcontinuously throughout the year then foodwill always be available. The second indicator is the purchase of rice which correlates negatively and this condition indicates that the purchase of rice will be reduced if high food availability in the sense if higher production, food availability is also high that the purchases of rice in the same period is also reduced.

The third factor determining the availability of food is cassava stock (84.6\%), sweet potato $(82.3 \%)$ and corn $(91.4 \%)$ which are not sold by farmers and can be used as food reserves. .

In the table above can also be seen that the $\mathrm{T}$-value $\geq 1.96$ and $\mathrm{P}$-value $\leq 0.05$ which means that all indicators on the outer loading met the requirement convergence validity as a valid factor to explain the availability of food in the border area.

In addition to evaluating the convergence of validity, evaluation of the model still needs to be done by discriminant validity by comparing the correlation coefficient of food availability indicator with the coefficient of food sufficiency which can be seen in the discriminant validity matrix.

The data also shows that there were 105 respondents $(56.38 \%)$ did not buy rice because the production of the previous planting season was still sufficient for consumption in the next month and only 83 respondents $(43.62 \%)$ had to buy rice every month.

Factors Affecting Farmers / Fishermen Farmers' Adequacy in Border Areas:

Based on the results of analysis of food ingredients consumed by the community, it is known that the intake of calories consumed by some farm households in the border area is sufficient to meet the nutritional requirements. Actual energy in all coastal areas has exceeded the amount recommended by the government $(2150 \mathrm{Kcal})$. As in the coastal area of Sempadan village (AKE score 2,586.4 kcal). the village of Camar Bulan $(2183.51 \mathrm{kcal})$ and Maludin $(2625.90 \mathrm{kcal})$ has exceeded the normative AKE score, except the Central River village $(2100.71 \mathrm{kcal})$ is still below the normative AKE. The average percentage score of the actual TKE is above $100 \%$ except the Central River village (97\%).

The data show that eventhough the AKE score in the household consumption of farmers has exceeded the normative score but the average PPH score of all villages in the Coastal Region is lower than the ideal PPH 
score of 100. Among the villages in the coastal area the highest consumption isSungai Tengah with a score of 76.80 PPH, followed by Maludin, Camar Bulan and Sempadan villages with a PPH score of 73.84, 69.30 and 65.51 .

The level sufficiency of proteinin each village in coastal area is 50.55 gram (TKP 87.45\%) Sempadan village, 50.85 gram (79.65\%) in Desa Camar Bulan, 50.47 gram (TKP 87.67\%) in Maludin Village and 49.89 gram (TKP 82.41\%) in the Sungai Tengah Village. The highest protein source was obtained from a group of food grains, animal food and nuts.

In the rural areas, it shows that from 11 villages only 5 villages showed their AKE score exceeding normative AKE that is Aruk village with actual AKE score reaching adequacy 2765,5 with TKE 128,63\%, village of Sajingan actual AKE score 2986,13 with TKE 138, 89\%, Tapang Ngole village actual score 2389,86 with TKE 111,16\%, Ngole village actual score AKE 2186.32 with TKE 101.64\%, Desa Sawah actual AKE score 2468,26 with TKE 114.80. Then from PPH score point of view it turns out all villages in the rural area less than $100 \%$.

Furthermore, protein consumption in Aruk village was 51,04 gram with TKP 89,55\%, Aping 51,10 gram with TKP 89.63\%, Sajingan village 51,08 gram with TKP 89,71\%, Tapang Ngole 51,19 gram with TKP 89 , $79 \%$ and other villages achievement of protein sufficiency rate (PPA) ranged between 51,08 gram - 56,89 gram. The largest source of protein contributor comes from a group of grain foods, animal foods and nuts.

In the table shows that the average foodstuff group in the coastal area is still dominated by the grain group of $29.9 \%$, animal poultr $27.5 \%$ and nuts by $13.6 \%$ while in Sajingan area food group is dominated by rice$(30.1 \%)$, animal poultry $(23.5 \%)$ and vegetables and fruits $(21.5 \%)$. Based on the TKE, TKP and PPH it can be concluded that the consumption of farmers has met the nutritional requirements but not balanced.

The results of the analysis in outer loading indicate that there are five indicators that have validation to reflect the construct sufficiency of food of farmers / fishermen household that have a significant effect on the level of food sufficiency. The correlation coefficient value shows the correlation between the exogenous latent variable with its formator indicator; first is the price of meat, second is the frequency of housewife come to visit the organization meeting in the village. The third indicator is the price of fish, the fourth indicator of farmer income and the fifth indicator is the number of family members.

The first indicator, the price of meat with coefficient correlation marked in negative -0.847 and the significant that the adequacy of food of farm households to be low when meat prices increase. The adequacy of household food is negatively correlated with meat price of $84.7 \%$. The conditions abovecan be explained that the adequacy of food correlation with the price of meat is very large reaches $84.7 \%$ so that food sufficiency is strongly influenced by meat price of $84.7 \%$. For farmers, meat are a special type of food and rarely consume except during special days. Increase meat prices ( Rp 100,000/ kg - Rp 120,000/ kg) causes people to eat less meat, which means food as a source of animal protein is also reduced. The price of chicken, fish and eggs is relatively more cheaper thus it becomes daily consumption and still purchased although at certain times the price also increases. The price of fish is relatively cheaper ( $\mathrm{Rp} .10 .000 / \mathrm{kg}-\mathrm{Rp} 30.000 / \mathrm{kg}$ ) compared to the price of meat and so that price of broiler relatife cheaper (Rp.30.000/ kg-Rp.35.000/ kg) compared to meat price. Beside the price is more cheaper than meat, its always available every day in the border stalls of the border area that is makes its more convenient by farm households.

The second indicator is the frequency of meetings of farmer mothers in village organizations with a correlation coefficient of 0.822 and significant that the adequacy of household food of farmers increases as the frequency of meetings of farmer mothers in village organizations is increased. The adequacy of household food is positively correlated with the frequency of meetings of rural women in village organizations by $82.2 \%$. The more frequent the meeting means do not miss information from the extension workers either from the agricultural service or from the health office that associated with the health of children and mothers including food and nutrition problems for the family.

From Puskesmas information in both coastal and rural areas, in every month they always come down to the villages with new and different topics in order to make the mother farmer feel loss if not attend. Each present they get additional knowledge and skills in preparing food intake for herself and her family. It can be said that the more often the organization meeting the broader the knowledge and skills it has and the impact on the increased quality of food consumed by her family. In addition to the number enough, the food menu is always considered in order to obtain a balanced diet. Therefore, the more often the farmer mothers follow the meeting in the village then the adequacy of the household food of farmers and their families will better.

The third indicator is the price of fish with a coefficient correlation marked positive at 0.624 and significant meaning that the adequacy of food of farm households to be better when fish prices increase.

The fourth indicator is the number of family members with a coefficient correlation at 0.469 and it is significant that the household food sufficiency of households increases as the number of family members is increased. The adequacy of household food is positively correlated with the number of members of 46.9 . Increasing the number of family members provides motivation for farmers to increase income and availability of food in their households. 
The fifth indicator is the farmer income with coefficient correlation marked positive at 0.464 and significant meaning that the sufficiency of food of farmer household to be better if farm income increase. Some efforts to increase farm income is through land expansion which there are two ways; harnessing unused land or extension and the second is intensification i.e. increasing crop intensity to $200 \%$ to 300 .

Factors Affecting Food Resilience:

Food Availability To Food Resilience:

The second exogenous latent variable is the availability of food showing the correlation coefficient of 0.398 positive and significant. This means that every increase of one unit of food availability affects 0.398 units of food resilience.

The Effect of Food Adequacy on Food Resilience:

The first exogenous latent variable, the adequacy of the food showed a correlation coefficient of 0.417 and it was significant that the adequacy of food from the farmer household was strongly correlated and determined the food resilience of $41.7 \%$. The greater the food sufficiency the food resilience tends to be more resistant and even very resistant. (Table 7.1)

The Effect of Land Supporting Capability on Food Resilience:

The first indicator to be positively correlated with food resilience is the carrying capacity of farm land. with correlation coefficient positive 0,922 and very significant means that land carrying capacity reflects food resilience $92,2 \%$. Food resilience is determined by the carrying capacity of agricultural land. because the higher the carrying capacity of the land the higher food resilience.

\section{Effect of Rice Reserve on Food Resilience:}

The second indicator that correlates positively to food resilience is food reserves for alternative supply. with correlation coefficient marked positive 0,756 and significant which means that food reserve reflect food resilience equal to $75,6 \%$. Food resilience is determined by food reserves. therefore to improve food security, food reserves need to be improved. in other words food resilience tends to increase with increasing food reserves.

Influence of Market Distance from Household toFood Resilience:

The next indicator that is positively correlated to food resilience is the market distance to households. with correlation coefficient marked positive 0,422 and significant meaning that distance reflect food resilience equal to $42,2 \%$. Food resilience is determined by the distance home to the market whichnowdays this distance is not a problem of society to maintain their food resilience because transportation facilities and infrastructure is quite good and every household already has a means of transportation. so that long distances do not prevent them from fulfilling their food needs.

Influence of Distance of Health Service from Household Against Food Resilience:

The negative correlated indicator of food resilienceis the distance of the household to the health service center. with correlation coefficient marked -0.316 and significant. This condition gives meaning that food security is getting lower with distance of health service from farmer household. The distance from the puskesmas to the household reflects the food resilience of $31.6 \%$. Food resilienceis determined by the distance of puskesmas because the farther the distance the food resilience is lower. The distances to the puskesmas are far too impressive for a long time to reach the puskesmas therefore it is considereddiscomfort to get health service.

Position of Food Resilience of Households in Border Area:

Another interesting information from the results of this research is that the nine basic moat commodities in the market and shops in the village border areas come from Malaysia because of its relatively close distance. In addition to rice, there are eight daily commodities from Malaysia purchased by the people, i.e. chicken eggs (Rp1500 / egg -Rp.2000 / egg), chicken meat (Rp 33.000-35.000 / kg), cooking oil (12.000-13.000 / kg) sugar (Rp10.000-Rp.9.000 / kg), onion and garlic (Rp 23.000-Rp.25.000) and packing gas 30kg / 16kg / net (Rp.150.000-Rp.160.000 / tube).

Based on the three subsystem analysis of food reliencethat have been described; food availability, food access and utilization covering 11 food relience indicators that are classified into five categories hence known status of food security of each coastal region and rural area as follows: Sambas District found consecutively farmer households in food insecurity conditions as much as $7 \%$, food susceptibility $12 \%$, food less $60 \%$, food resistant $15 \%$ and very food resistant $7 \%$. While in rural areas farm households are also divided into five 
categories: food insecurity by $8 \%$, food susceptible as much as $22 \% .53 \%$ food insecurity, $14 \%$ food and very resistant 3\% while in coastal area 3\% food insecurity, 26\% susceptible food, $49 \%$ less food, $14 \%$ food resistant and $8 \%$ very food resistant. Judging from the distribution of the percentage of food relience status, it is concluded that generally the farmers' households in the border area are in poor condition.

\section{Conclusions And Recommendations:}

Conclusions:

Based on the results of research and discussions that have been described can be summed up things as follows :.

1. Production of rice, corn, cassava, and sweet potato reservesstocks have a significant and positive effect on food availability in the sense that the higher production and food reserves are being prepared, the higher food availability.

2. The frequency of meetings of farmer mothers, fish prices, number of family members, farm income, positive and significant effect on food sufficiency, while the price of meat is negatively correlated and significant to the adequacy of food. The better the knowledge of housewives about nutrition and kesaehatan then the better in managing the resources they have and the menu of family food, the more fulfilled family food.

3. The higher the carrying capacity of the land, the rice reserves and the closer the distance from the market, the availability of food and the adequacy of food influence the better food security in the border area

4. The contribution of on-farm incomes in Coastal Areas can meet 100\%, food expenditure, while in the rural area the contribution of on-farm income can only meet $90.58 \%$ of food expenditure. Most coastal and rural farmers earn on-farm income ranging from 58-65\%. off-farm ranges from 17 - 33\% and non-farm ranges from 9 $-18 \%$.

5. Actual energy sufficiency (AKE) in both Coastal and Rural Areas has complied with normative norms and normative TKE reaches $100 \%$ but the new PPH score reaches $65.51-76.8 \%$ which identifies food intake is not balanced yet and still dominated by food grains. Actual PPA scores are still below the normative AKP ranging from 49.89 - 56.89 grams.

6. Overall, farmers' households are in a very food resistant condition of $7 \%$, food resistant $15 \%$, less resistant by $60 \%$, vulnerable by $12 \%$ and prone to $7 \%$. Viewed from the region, in food-susceptible uplands - less food security by $83 \%$, then coastal areas by $78 \%$. Thus it can be concluded the food resilience in coastal areas better than rural areas.

\section{Recommendations:}

Based on the conclusionsabove, there are some suggested that can be considered as follow:

1. For the availability of food, farmers / fishermen's households should expand their farms since there are still unproduced land ranging from 1-2 ha and increase the use of herbicide and fertilizer stocks.

2. To increase the adequacy of foodthere is need to increase counseling, especially about the knowledge about balanced food consumption, family financial management, broad cultivation of the perain.

3. To improve food resilience to the community should be given counseling about food resilience and postharvest management

4. The community still needs assistance and help in preparation of clearing land so that the area of farming can be expanded through the procurement of agricultural mechanization equipment and operator training.

5. Especially in the coastal areas need assistance of financial management and infrastructure facilities of fishing gear and navigation tools so that self-help farmers group can take care of their own needs at a cheaper cost including building mini ice factory.

\section{REFERENCES}

[1] Badan Pusat Statistik, 2013. Survei Sosial Ekonomi Nasional /Susenas. Jakarta: Badan Pusat Statistik Republik Indonesia.

[2] Badan Pusat Statistik, 2016. BPS Kabupaten Sambas tahun.

[3] Bambang, J.S., N. Musriyadi, Sri Sugiarti, 2012. Faktor Faktor yang Mempengaruhi Tingkat Kecukupan Gizi Mandiri Pangan, di Desa Barat Wetan Kecamatan Kabawen Kabupaten Kapahiang Propinsi Bengkulu. Jurnal Agribis, IV-1.

[4] Farhan, M., 2013. Kecukupan Konsumsi Pangan Hewani di Kota Jambi dalam Hubungannya Kualitas Sumberdaya Manusia Rumah Tangga Petani serta Faktor-Faktor yang Mempengaruhinya. Jurnal Ilmiah Ilmu-Ilmu Peternakan, XI(2): 81-87.

[5] Ghozali, Imam dan Hengky Latan, 2014. Partial Least Square ; Konsep, Teknik, dan Aplikasi Menggunakan Program SmartPLS 3.0 Untuk Penelitian Empiris. Semarang. Badan penerbit Universitas Diponegoro Semarang.

[6] Hamid, Y., S. Budi, Suhartini, 2013. Analisis Pola Konsumsi Pangan Rumah Tangga (Studi Kasus di Kecamatan Tarakan Barat Kota Tarakan Propinsi Kalimantan Timur). Agrise, XIII(3): 175-190. 
[7] Hanani, N., 2012. Strategi Pencapaian Ketahanan Pangan Rumah tangga petani. Bogor: Perhepi e-journal, $1-1$.

[8] Halik, A., 2007. Ketahanan Pangan Masyarakat Pedesaan (Studi Kasus di Desa Pammusureng, Kecamatan Bonto Cani, Kabupaten Bone. Jurnal Agrisitem, 3-2.

[9] Hariyanti, Y., S. Suharto, 2012. Ketahanan Pangan, Kemiskinan Dan Solusinya di Asean. E-Journal Ekonomi Pertanian, 1(1): 35-44.

[10] Haryono, Siswoyo, 2017. Metode SEM Untuk Penelitian Manajemen AMOS LISREL PLS. Jakarta. Penerbit Luxima Metro Media.

[11] Monografi Kecamatan, 2014. kecamatan Sajingan Besar dan Kecamtan Paloh. Kabupaten Sambas

[12] Moenek, A., 2007. Gerakan Percepatan Diversifikasi Konsumsi Pangan 2007-2015.Makalah Pertemuan Koordinasi Pemberdayaan Perbaikan Ekonomi dan Gizi Keluarga Hotel Panghegar, Bandung.

[13] Mailoa, M., 2012. Diversifikasi Konsumsi Pangan Pada Masyarakat Negeri Hatusua Kabupaten Serang Bagian Barat. 53-66.

[14] Mudakir, B., 2011. Produktivitas Lahan Dan Distribusi Pendapatan Berdasarkan Status Penguasaan Lahan Pada Usahatani Padi (Kasus Di Kabupaten Kendal Propinsi Jawa Tengah). Jurnal dinamika ekonomi pembangunan. 1. 74-84.

[15] Mun'im. Akhmad, 2011. Analisis Pengaruh Faktor Ketersediaan. Akses dan Penyerapan Pangan Terhadap Ketahanan Pangan di Kabupaten Surplus Pangan: Pendekatan Partial Least Square Path Modeling.

[16] Muta'ali, L., 2012. Daya Dukung Lingkungan untuk Perencanaan Pengambangan Wilayah . Yogyakarta. Badan Penerbit Fakultas Geografi (BPFG) UGM.

[17] Rosyadi, I., D. Purnomo, 2007. Tingkat Ketahanan Pangan Rumah Tangga di Desa Tertinggal . jurnal Ekonomi Pembangunan, 304-315.

[18] Sari, L., D. Iva, 2010. Ketertsediaan Pangan di Kabupaten Rokan Hulu. Jurnal Ekonomi, 18-2.

[19] Sugiyono, 2012. Metode Kunatitatif, Kualitatif dan R\&D. Penerbit Alfabeta. Bandung.

[20] Surachman, 2013. Faktor Sosial Ekonomi Yang Mempengaruhi Keanekaragman Konsumsi Pangan Desa Mandiri Pangan Kabupaten Kubu Raya, Thesis, Magister Manajemen Agribisnis, Universitas Tanjung Pura, Pontianak

[21] Suryana, A., 2004. Ketahanan Pangan di Indonesia Makalah pada Widyakarya Nasional Pangan dan Gizi VII, Jakarta 17-19. Mei . LIPI UNDP, 1990, Human Developmentb Report, Nery York : Oxford University Press.

[22] Widada, A.W., Masyhuri, H.M. Jangkung 2017. Determinant Factors of Food Security in Indonesia. Agro Ekonomi, 28-2.

[23] Owino, A.Y., K.A, Leonard, W. Ronald, Fabian Nabugoomu, S.K. Elijah, Z. Muwanga, 2014. Determining Factors that Influence Household Food Insecurity in Uganda:A Case Study of Tororo and Busia Districts, 14(1): 394-404. 